Kom, 2013, vol. II (1) : 1-15

UDC: 14 Генон P.

168.522:111

Original scientific paper

\title{
René Guénon's Doctrine of Metaphysics as Foundation of IsLamic Humanities
}

\author{
Roland Pietsch \\ Ukrainian Free University, Munich, Germany
}

\begin{abstract}
René Guénon, known in the Islamic world as Shaykh 'Abd al Wāḥid Yahyāā (1886-1951), was one of the most important representatives of the Sophia perennis (Guénon 2001a: 77, Schuon 1979: 133-137) in the twentieth century.

His works are mainly concerned with a profound critique of the modern world from a metaphysical point of view, a renewed exposition of the immutable principles of universal metaphysics, the traditional sciences and finally symbolism.

The following paper presents at first the main elements of universal metaphysics. Then the relation between metaphysics and sciences will be demonstrated, whereas the difference between traditional and modern sciences will be examined. After that, follows a short presentation of some elements of traditional sciences of logic and mathematics.
\end{abstract}

Keywords: René Guénon, metaphysics, the pure intellect, traditional sciences, Islamic humanities, logic, mathematics, geometry

\section{Metaphysics}

For explaining metaphysics, René Guénon ${ }^{1}$ told in his lecture at the University Sorbonne in 1925: "It should be made clear just what is meant by the word 'metaphysics', and all the more so since I have frequently had an opportunity to note that not everyone understands it in quite the same way. I think

\footnotetext{
Corresponding author: roland.pietsch@t-online.de
}

1 On the life and work of René Guénon see: Chacornac 1958, Laurent 1975, id. 2006, Robin 1983, id. 1986, Gilis 1986, Sigaud 1984, Waterfield 1987, Lognetti 1996, Accard 2001, id. 2005, Vivenza 2002, Feydel 2003, Schuon 2004, de Maistre 2004, 'Abd al-Halim 2007. 
the best course to take in dealing with words that might give rise to ambiguity is to restore to them as much as possible their primal and etymological meaning. Now, according to its composition, the word 'metaphysics' means literally 'beyond physics', taking the word 'physics' in the accepted sense it was always used by the ancients, that is to say as 'knowledge of nature' in the widest sense. Physics is the study of all that pertains to the domain of nature; metaphysics, on the other hand, is the study of that which lies beyond nature" (Guénon 2001a: 88), and thus is supernatural.

René Guénon states that it is not possible to define metaphysics, "because to define is always to limit, and what is under consideration, in and of itself, is truly and absolutely limitless and thus cannot be confined to any formula or any system whatsoever" (Guénon 2004: 89 f). Metaphysics can only be partially characterized, for example, that it "is essentially the knowledge of the Universal, or the knowledge of principles belonging to the universal order, which moreover alone can validly lay claim to the name of principles" (ibid.: 71).

Thus the metaphysical knowledge differs radically from the other modes of human knowledge. This raises the question of which approach to metaphysics can be found.

Before Guénon answers, he states: "Metaphysics can only be studied metaphysically" (ibid.: 74). Basically, it is considered that metaphysical conceptions "can never be completely expressed, nor even imagined, since their essence is attainable by the pure and 'formless' intelligence alone; they vastly exceed all possible forms, especially the formulas in which language tries to enclose them, which are always inadequate and tend to restrict their scope and therefore distort them. These formulas, like all symbols, can only serve as a starting-point, a 'support' so to speak, which acts as an aid towards understanding that which in itself remains inexpressible; it is up to each man to try to conceive it according to the extent of their own intellectual powers, making good, in proportion to their success, the unavoidable deficiencies of formal and limited expression" (ibid.: $74 \mathrm{f}$ ).

\section{The pure intellect and metaphysical knowledge}

A very important aspect of metaphysics concerns the means of metaphysical knowledge. Metaphysical knowledge as a knowledge of the Universal doesn't know the distinction between subject and object. When one also speaks of the means of attaining metaphysical knowledge, "it is evident that such means can only be one and the same thing as knowledge itself, in which subject and object are essentially unified" (ibid.: 75). It follows from this that the means in question is not a discursive faculty such as individual human reason. On the contrary, "metaphysical truths can only be conceived by the 
use of a faculty that does not belong to the individual order, and that, by reason of the immediate character of its operation, may be called 'intuitive"' (ibid.: $75 \mathrm{f}$ ), but intuition not understood as the instinctive and vital faculty of some modern philosophers.

"To be more precise, it should be said that the faculty we are now referring to is intellectual intuition, the reality of which has been consistently denied by modern philosophy, which has failed to grasp its real nature whenever it has not preferred simply to ignore it; this faculty can also be called the pure intellect, following the practice of Aristotle and his scholastic successors, as to them, the intellect was in fact the faculty which possessed a direct knowledge of Principles" (ibid.: 76). Guénon quotes in this context two sentences of Aristotle's: "The intellect is truer than science" and "nothing is more true than the intellect" (Aristotle's 1993: Book II, Ch. 19. 100 b.), "for it is necessarily infallible from the fact that its operation is immediate and due to not being really distinct from its object, it is identified with truth itself" (Guénon 2004: 76) This means "the fundamental identity of knowing and being ... and since this identity is essentially implied in the very nature of intellectual intuition, it not merely affirms it but realizes it as well. This is true at least of integral metaphysics" (ibid.: 115). Metaphysics remains as such "fundamentally and unalterably the same, for its object is one in its essence, or to be more exact 'without duality (advaita)', as the Hindus put it, and that object, again by the very fact that it lies 'beyond nature', is also beyond all change: the Arabs express this by saying that 'the doctrine of Oneness is one"” (ibid.: 73), at-tawhịidu wāḥidun.

Concerning metaphysical knowledge or intellectual intuition one can say it is derived from the pure intellect. By contrast, scientific or discursive knowledge is basically synonymous with indirect, mediate knowledge; it is therefore a completely relative knowledge and it is derived from reason, "which has the general for its domain since, as Aristotle has declared, there is no science but that of general"' (ibid.: $76 \mathrm{f}$ ). The general is not the universal (see: Vivenza 2004).

\section{Relation between Metaphysics and traditional Sciences}

The relation between metaphysics and traditional sciences is based on the traditional approach, which means that the sciences are part of traditional forms, that is to say, religions are rooted in metaphysics. That root gives rise of stability to traditional sciences being derived as indubitable consequences of truths.

In Islamic civilization, for example, the intellectual intuition, which can be understood as the pure metaphysical doctrine of all religious teachings is 
the essence and everything else is connected with it. It is the root of all the scientific findings and phenomena originating out of it and being connected to it, either consequentially or by the application to various orders of contingent reality (Guénon 1996: 6).

This is especially true for traditional science, as "that is to say of knowledge bearing on the domain of the relative, knowing which, in such civilizations, cannot be regarded otherwise than as a mere dependency and as a sort of prolongation or reflection of absolute or principal knowledge" (ibid.: 61).

Every traditional civilization has had such traditional sciences because they belong to the realm of adaptations giving rise to multiplicity. Hereby all the complex conditions have been taken into account, mental, social or other of the people inheriting them, whereas readjustments were necessary from time to time to adapt the ever-changing social conditions. But these readjustments can be considered as changes only in form, not touching the essence of tradition, the metaphysical doctrine. Thus "these readjustments are only changes of form, which do not touch the essence of the tradition: with a metaphysical doctrine, only the expression can be modified, in a way that is more or less comparable to translation from one language into another; whatever may be the form it assumes for its expression, in so far as expression is possible, there is still absolutely only one metaphysic, just as there is only one truth" (ibid.: 62).

Traditional sciences belong to the world of forms and multiplicity. The different forms constitute different sciences, even if they have the same subject-matter. The multiplicity of forms gives rise to an indefinite number of possible sciences and therefore, it may happen that different sciences study the same things, but from a totally different angle and approach thus legitimizing being called different sciences (ibid.: 63).

This concept of traditional sciences is radically opposed to the concept of modern sciences. The traditional concept attaches all the sciences to the principles of which they are the particular applications. Their meanings are identical, despite "claims to make the sciences independent, denying everything that goes beyond them, or at least declaring it 'unknowable' and refusing to take it into account, which comes to the same thing in practice" (ibid.: $65 \mathrm{f}$ ).

That means that modern sciences want to deny their root, their higher principle, which they originated from. Of course it is done under the assurance that this step is necessary to ensure its independence. Modern sciences are ripped off of all deeper meaning, and thus led into a blind alley, where they become isolated from all other truths, being trapped in a hopelessly limited realm of separation. This makes modern sciences prone to ever ongoing change, because they have lost the connection to their metaphysical root. 
"In taking on its modern form, science has lost not only in depth but also, one might say, in stability, for its attachment to the principles enabled it to share in their immutability in the full measure that its subject-matter allowed, whereas being now completely confined to the world of change, it can find nothing in it that is stable and no fixed point on which to base itself" (ibid.: 67). And "as far as modern science is concerned, the conclusion in question can only belong to the realm of hypothesis; whereas the teachings of the traditional sciences had a very different character, coming as the indubitable consequences of truths known intuitively, and therefore infallibly, in the metaphysical order" (ibid.: 68).

Having a traditional approach we can say that every science is legitimate, as long as it keeps the place it belongs to in virtue of its own nature. That means that according to the traditional conception, any science is of interest less in itself and is regarded as a prolongation or extension of the doctrine whose essential part consists in pure metaphysics. Having taken this point of view, we can easily see that all the knowledge of lower order, meaning knowledge being devoid of its root, is of much lesser interest, than the knowledge being expressed as a reflection of its root, because it is leading us always to the root that it came from. Therefore we must never lose sight nor sacrifice this connection to more or less accidental considerations of the mind.

So we can recognize two functions of the principal knowledge; on the one hand, it is a reflection of the origin it's rooted in, and on the other hand, it is a reflection of the knowledge in a certain contingent domain.

"These are the two complementary functions proper to the traditional sciences: on the one hand, as applications of the doctrine, they make it possible to link up the different orders of reality and articulate them into the unity of a single synthesis; and on the other hand, they constitute, for some people at least, and in accordance with their individual aptitudes, a preparation for a higher knowledge and a way of approaching it, and by virtue of their hierarchical arrangement according to the levels of existence to which they refer, they form, as it were, so many rungs by which it is possible to climb to the level of pure intellectuality. It is only too clear that modern sciences cannot in any way serve either of these purposes; this is why they can be no more than 'profane science', whereas the traditional sciences, through their connection with metaphysical principles, are effectively incorporated in 'sacred science"' (ibid.: $74 \mathrm{f}$ ).

When taking all the aspects of traditional sciences in account, we must ask the question who is qualified for sciences in traditional way. What prerequisites 
are necessary for such a one? Guénon states that "sciences can only be validly constituted as sacred science by those who, before all else, are in full possession of the principal knowledge and are thereby alone qualified to carry out, in conformity with the strictest traditional orthodoxy, all the adaptations required by circumstances of time and place" (ibid.: 76).

That reminds us of the Aristotelian age, where politicians, artists and scientists first had to realize the origin of all existence and multiplicity, before being regarded as fully capable to execute the different arts in order to display and keep the origin present in one's work and to act in accordance with the origin itself.

Contrary to modern sciences, where all achievements are obtained in order to promote the scientist's reputation and which are only directed outwards, the traditional teachings are established in such a way that they are directed inwards. They are set up in that way so that they can be considered as 'illustrations of the pure doctrine. These illustrations of the original root are deemed to be more easily accessible to the ordinary mind, than the pure doctrine itself. Also, in the realm of multiplicity, it delivers an almost indefinite variety of aspects and points of view of the divine origin. But according to Guénon, "any of these preparatory degrees are absolutely necessary, since they are mere contingent methods having no common measure with the end to be attained;" In his opinion "it is even possible for some persons, with whom the tendency to contemplation is predominant, to attain directly true intellectual intuition without the aid of such means; but this is a more or less exceptional case" (ibid.).

Then Guénon draws a comparison to the wheel of life or to what is also known as cosmic wheel, Bhavachakra. This is a basic image, existing in Hinduism as well as in Buddhism. Guénon states: "The whole question may also be illustrated by means of the traditional image of the 'cosmic wheel': the circumference in reality exists only in virtue of the centre, but the things who stand upon the circumference must necessarily start from there, or more precisely from the point thereon at which they actually find themselves, and follow the radius that leads to the centre. Moreover, because of the correspondence that exists between all the orders of reality, the truths of a lower order can be taken as symbols of those of higher orders, and can therefore serve as 'supports' by which to arrive at an understanding of these; this fact makes it possible for any science to become a sacred science, giving it a higher or 'anagogical' meaning deeper than that which it possesses in itself" (ibid.: 77).

Every science, Guénon says, "can assume this character, whatever may be its subject-matter, on the sole condition of being constructed and regarded from the traditional standpoint; it is only necessary to keep in mind the degrees of importance attached to the various sciences according to the hi- 
erarchical rank of the various realities studied by them; but whatever degree they may occupy, their character and functions are essentially similar in the traditional conceptions" (ibid.: $77 \mathrm{f}$ ).

\section{Islamic Humanities}

René Guénon's main concern according to rational sciences was to show that, in different traditions or religions, sciences can only be called traditional when the relations of these sciences to their metaphysical principles are existent. Guénon was not concerned extensively with Islamic traditional sciences at length. There are only some rare treatises on Islamic Humanities (Guénon 1962: 48-54, 151-155, cf. 1973: 62-75). Nevertheless one can speak of Islamic Humanities sciences without limitations in his context, because these are nothing else than traditional sciences. Out of the abundance of traditional Humanities and sciences we will discuss logic, mathematics and geometry, because "logic and mathematics (and geometry) may be said to be the two sciences having the most real affinity with metaphysics" (Guénon 2004: 95) but at the same time they are "confined within the limits of reason and within the category of individual conceptions, it follows that they are still radically separated from pure metaphysics" (ibid.).

\section{Logic}

Logic in a traditional doctrine "is exclusively a rational science, metaphysical exposition may assume an analogous aspect with regard to its form, but with regard to its form only, and if it must then comply with the laws of logic, that is because these laws themselves rest on essentially metaphysical basis, without which they would have no validity; at the same time, however, if it is to possess a truly metaphysical bearing, this exposition must always be formulated in such a way as to leave open possibilities of conception as limitless as the domain of metaphysics itself" (ibid.: 96).

The Hindu tradition makes available an example of traditional logic in the form of Nyâya, which is one of the six classical systems or darshanas of Hindu philosophy described by René Guénon. Nyâya is a Sanskrit word which means method, rule and also logic. The ultimate goal of Nyâya is the deliverance from error and illusion and finally liberation through knowledge. Therefore "Hindu logic considers not only the manner in which we conceive of things, but also the things themselves insofar as they are conceived by us, since our conception would have no reality if it were entirely separate and distinct from its object" (ibid.: 172). Guénon contrasted this with the alleged doctrine of Greek philosophers; for them logic was exclusively concerned with the relations between 
ideas, as if it was only through these that things are known. Of course, rational knowledge is only indirect knowledge, and for that reason open to error; yet, if it could not reach things themselves to a certain extent it would be entirely illusory and could not be called knowledge in any sense of the word. If at all it may be said that under the rational mode an object can only be known through the intermediary of its notion and this can only be because the notion possesses something of the object itself and shares it in its nature by expressing it in relation to ourselves (ibid.). Then Guénon quoted the famous Scholastic definition of truth: Veritas est adaequatio rei et intellectus (truth is the correspondence of a thing and the intellect). This definition in all the degrees of knowledge is that "which comes nearest, in the West, to the point of view of the Eastern traditional doctrines, because it confirms most nearly to the purely metaphysical conception" (ibid.).

But Guénon regretted that the "Scholastic doctrine... did not quite succeed in breaking loose from the limitations which were its inheritance from the Hellenic mode of thought" (ibid.: 173). Guénon regretted too, "that the Scholastics never grasped the profound consequences implied in the principle, already laid down by Aristotle, of identification through knowledge" (ibid.).

"It is precisely in virtue of this principle that from the moment the subject knows an object, however fragmentary or superficial that knowledge may be, something of the object is present in the subject and has become part of its being. ... The act of knowledge presents two inseparable facets; it is an identification of the subject with the object; it is also, for the self-same reason, an assimilation of the object by the subject: by reaching things in their essence, we 'realize' them... as states or modalities of our own being; and if the idea, in the measure in which it is true and adequate, shares in the nature of the thing, it is because, conversely, the thing itself shares also in the nature of the idea" (ibid.).

\section{Mathematics}

René Guénon was concerned with Mathematics all his life. In 1946 he published The Metaphysical Principles of the Infinitesimal Calculus. In the conclusion of this book he wrote: "Moreover, it should be said that, more than any other science, mathematics thus furnishes a particularly apt symbolism for the expression of metaphysical truths to the extent that the latter are expressible" (Guénon 2001b: 130).

In this work Guénon considered the nature of limits and the infinite in relation to calculus. Contemporary mathematics provided evidence for him that the sciences as we know them are debased residues of traditional sciences from which they derived, because they have lost all relations to 
higher metaphysical principles. Contemporary mathematicians "seem to be ignorant of what number truly is; and by this we do not mean to speak solely of number in the analogical and symbolic sense... but even of number in its simply and strictly qualitative sense. Indeed, their entire science is reduced to calculation in the narrowest sense of the word, that is, to a mere collection of more or less artificial procedures, which are, in short, only valuable with respect to the practical applications to which they give rise" (ibid.: 2). According to this Guénon points out that numbers should be replaced with numerals, a process which could only be counteracted by a deeper knowledge of true metaphysics. "From this viewpoint we will only add that when one completely loses sight of the meaning of a notation it becomes all too easy to pass from a legitimate and valid use of it to one that is illegitimate and in fact no longer corresponds to anything, and which can sometimes even be entirely illogical" (ibid.: 4).

An example of illogical mathematical operation is the use of "infinite" where "indefinite" would be the appropriate term. A correct understanding of "infinite" is necessary for a true metaphysical understanding, because it makes possible the ability to differentiate between the infinite and indefinite. The importance of this distinction follows from Guénon's considerations of the nature and structure of being, which is founded in the metaphysical concept of the infinite. He wrote in The Multiple States of Being: "To understand properly the doctrine of the multiplicity of the states of being, it is necessary to return, before considering anything else, to the most primordial of all ideas, namely to that of metaphysical Infinity envisaged in its relationship with universal Possibility" (Guénon 1985: 27). The Infinite is a metaphysical concept; it is that which is without limits and thus beyond time and space. It is that which contains within itself all possibilities. Thus it is beyond all definitions and any way to treat Infinity as a mathematical term is illegitimate. Infinity is beyond form and at the level of Divine unity (tawhid). The Infinite cannot be comprehended by affirmative statements. Any attempt to describe it must rely on the negation of limited affirmations: "Consequently, the negation of a limit is in fact the negation of a negation, which is to say, logically and even mathematically, an affirmation. Therefore the negation of all limits is equivalent, in reality, to total and absolute affirmation" (ibid.: 29 f). Therefore the Infinite is the most affirmative of all because it embraces all particular affirmations and "can only be expressed by a negation by reason of its absolute indetermination" (ibid.: 30). But the metaphysical idea of the Infinite "can be neither discussed nor contradicted, since there is nothing negative about it" (ibid.: 30). The Infinite is identical to the Whole. "It is important to observe, moreover, that the Whole in this sense must not be assimilated to a particular or determined 'whole' which has a definite relationship with the parts of which it consists. It is, properly 
speaking, 'without parts', for these parts would be of necessity relative and finite, and could thus have no common measure with it, and consequently no relationship with it, which amounts to saying that they have no existence from its point of view" (ibid.: 31). That which was said of the universal Whole applies to the universal and total Possibility and the universal Possibility is an example of the Infinite.

In contrast to the Infinite, the finite is determined, contingent and relative. The finite and the Infinite are irreducibly different. The concept of the limit in infinitesimal calculus demands that it should be conceived of as a final term in a continuous variation. Guénon stated that "the true notion of continuity does not allow infinitesimal quantities to be considered as if they could ever equal zero, for they would then cease to be quantities" (Guénon 2001b: 70). He criticized Leibniz's formulation of continuity on the grounds that it permits passing the limit without recognizing that they belong to different genera: "Such a conception of continuity, which ends up abolishing not only all separation, but even all effective distinction, in allowing direct passage from one genus to another without reducing the two to a higher or more general genus, is in fact the very negation of every true logical principle; and from this to the Hegelian affirmation of the identity of contradictories' is then but one step which is all too easy to take" (ibid.: 77). And "a limit cannot be reached within a variation, and as the term of the latter; it is not the final value the variable takes on, and the idea of a continuous variation arriving at any 'final value', or 'final state', would be as incomprehensible and contradictory as that of an indefinite sequence arriving at a 'final term', or of the division of a continuum arriving at 'final elements" (ibid.: 125). And further Guénon stated that "a limit of a variable must truly limit, in the general sense of the word, the indefinitude of the states or possible modifications comprised within the definition of this variable; and it is precisely for this reason that it must necessarily be located outside of what it limits" (ibid.). The limit cannot be attained logically by exhausting the indefinite number of states: it demands passing from the domain of variation, which does not contain the limit "not analytically and by degrees, but synthetically and in a single stroke, in a manner that is, as it were, 'sudden' and corresponds to the discontinuity produced in passing from variable to fixed quantities" (ibid.: 126). This transition can be compared to what happens when a rope breaks under tension: "the rupture itself is also a limit, namely of the tension, but it is by no means comparable to tension, whatever the degree" (ibid.). From all this one understands the need "to link science back to principles; it goes without saying that there should no longer be any reason to stop there, and one will quite naturally be led back to the traditional conception according to which a particular science, whatever it might be, is less valuable for what it 
is in itself than for the possibility of using it as 'support' for elevating oneself to knowledge of a higher order” (ibid.: 129).

Traditional explanations of the universe used numbers to represent the process in its origin and structure. In these explanations number acquired symbolical meanings which were continued in traditional sciences such as angelology of the Arabic alphabet, astrology, chiromancy. A traditional science of number is represented in sacred philology, in Greek and Islamic Pythagoreanism, which provided a mathematically founded cosmology. "Contemporary mathematicians seem to have reached a stage where they are unaware of the true nature of number, for they reduce the whole of their science to calculation, which in their case simply amounts to a mass of artificial procedures. This is equivalent to saying that they have replaced numbers with numerals (le nombre par le chiffre)" (Guénon 1976: 79). The fault of understanding the metaphysical significance of numerical concepts such as Infinity and Unity leads to illogicalities. "Strictly speaking numerals are just clothes for numbers. They are not even their body which is more legitimately represented by a geometric form, which to a certain degree may be considered as the true body of the number so that they show the theories of the Ancients on polygons and polyhedrons in direct relation to the symbolism of the numbers. This is not to say that numerals themselves are simply signs whose form derives from a purely arbitrary choice. Some languages do not differentiate between numerical and alphabetical characters, and some numbers, like letters, will have had a hieroglyphic, i.e. ideographic or symbolic origin" (ibid.).

\section{Geometry}

Geometry was, from its ancient origins on, one of the most important sciences. Its role in Pythagorean and Platonic philosophy is well known. Traditional geometry is for Guénon above all the science of measurement. "The idea of measure is intimately connected with that of 'order' (in Sanskrit rita), and 'order' is in turn related to the production of the manifested universe, the universe being, according to the etymological meaning of the Greek word kosmos, a production of 'order' out of 'chaos', the latter being the indefinite in the Platonic sense, and the 'cosmos' the definite... In this connection, the biblical statement may be recalled, according to which God has 'arranged all things by measure and number and weight' (Wisdom of Sol. 11: 20); these three categories clearly represent diverse modes of quantity, but they are only literally applicable to the corporeal world and to nothing else, though by an appropriate transposition they may nevertheless also be taken as an expression of universal 'order'. The same is also true of the Pythagorean numbers, but the mode of quantity that is primarily associated with measure, 
namely extension, is the mode that is most often and most directly brought into relation with the process of manifestation itself, by virtue of a certain natural predominance of spatial symbolism in this connection, arising from the fact that space constitutes the 'field' (in the sense of the Sanskrit kshreta) within which corporeal manifestation is developed, corporeal manifestation being inevitably taken as the symbol of the whole of universal manifestation" (Guénon 1995: 27 f). Therefore, for Guénon, spatial symbolism (see: Barazzetti 1997) is indispensable to expressing metaphysical issues.

The starting point of traditional or sacred geometry is the point symbolizing primordial unity. In this context René Guénon points out that Pascal's definition of space as 'a sphere which has its centre everywhere and its circumference nowhere' ${ }^{\prime}$ is not suitable in the metaphysical perspective when space is used to represent total being. "Thus, in space, considered in its existing reality and not as a symbol of the total being, no point is or can be the centre; all points equally belong to the domain of manifestation, by the very fact of belonging to space. Space is one of the possibilities whose realization falls within the domain, which, in its entirety, constitutes no more than the circumference of the 'wheel of things', or what might be called the outwardness of universal Existence" (Guénon 1975: 128). This will correspond to the Daoist text: "The point which is the pivot of the norm is the motionless centre of a circumference on the rim of which all contingencies, distinctions and individualities revolve" (ibid.: 129/ Ch'uang-tzu, ch. II). Therefore "it is the centre that is, rightly speaking, nowhere, because ... it is essentially 'non-localized': it is not to be found anywhere in manifestation, since it is absolutely transcendent in respect thereof, while being at the centre of all things. It is beyond all that lies within the scope of the senses or any faculty proceeding from the sensible order" (ibid.). In summary, it may be said that not only in space but in all that is manifested, what is everywhere is the exterior or the circumference, whereas the centre is nowhere since it is unmanifested; but (and here the expression 'inverse sense' takes on the full force of its meaning) the manifested would be absolutely nothing without that essential point, which in itself is not manifested at all, and which, precisely by reason of its non-manifestation, contains in principle all possible manifestations, being the 'motionless mover' of all things, the immutable origin of all differentiation and modification. This point produces the whole of space (as well as all other manifestations) by, as it were, issuing from itself and by unfolding its virtualities in an indefinite multitude of modalities,

1 This definition is in reality the second principle of the famous Medieval "Liber XXIV philosophorum": Deus est sphaera infinita, cuius centrum est ubique, circumferentia (vero) nusquam. (Baeumker 1927: 194-214). 
with which it fills space in its entirety; but when we say that the issues from itself to effect this development, such a very imperfect expression must not be taken literally. In reality, since the principial point is never subject to space, and since the relationship of dependence (or causal relationship) is obviously not reversible, this point remains "unaffected by the conditions of any of its modalities and consequently never ceases to be identical with itself. When it has realized its total possibility, it is only to come back (though the idea of 'returning' or 'beginning again' is in no way applicable here) to the 'end which is identical to the beginning', that is, to the primal Unity which contains everything in principle, a Unity which, being Itself (considered as the 'Self'), can in no way become other than Itself (for that would imply a duality), and from which, therefore, when considered in Itself, It had never departed" (ibid.: 130).

In his famous book "Symbolism of the Cross", which was published in 1931 in Paris and dedicated to Esh-Sheikh Abder-Rahman Elish El-Kebir El-Âlim el-Maghribi, René Guénon presents very systematically the basic idea of spatial symbolism and sacred geometry: "In geometrical terms, the three-dimensional cross forms a 'system of co-ordinates' to which the whole of space can be referred; here space will symbolize the sum total of all possibilities, either of a particular being or of universal Existence. This system is formed by three axes, one vertical and two horizontal, which are three perpendicular diameters of an indefinite sphere, and which, even independently of any astronomical considerations, may be regarded as oriented toward the six cardinal points. ... It may be also said that the vertical axis is the polar axis, that is, the fixed line which joins the two poles and about which all things accomplish their rotation: it is therefore the main axis, whereas the two horizontal axes are only secondary and relative. Of the two latter, the North-South axis may be called the solstitial axis, and the other the equinoctial axis, and this brings us back to the astronomical standpoint, by virtue of the correspondence between the cardinal points and the phases of the annual cycle" (ibid.: $21 \mathrm{f}$ ).

\section{Conclusion}

René Guénon has pointed out with great brilliancy the breach between traditional and modern sciences. The breach mainly consists in the fact that modern sciences aren't rooted in the metaphysical principles. This autonomy of modern sciences, in particular the modern philosophy is expressed in Descartes' "Cogito, ergo sum (I think, therefore I am)".

Guénon has made clear, with his evidence of a breach between traditional and modern Humanities and sciences, that it is quite possible to question 
the modern Humanities and sciences of the present, which in fact develop very fast, for their metaphysical principles. A large part of the modern $\mathrm{Hu}$ manities and sciences are concerned only about aspects of the reality. These relative realities are, to a certain extent, metaphysically regarded as a mirror of the absolute reality. It is however impossible to transform these modern Humanities and sciences into Islamic Humanities and sciences simply by labelling them with the epithet "Islamic". On the contrary, it is necessary to permeate and to understand the reality the science is concerned about, metaphysically, because the universal metaphysics, of which some aspects had been highlighted, embrace all and everything (Guénon 2004: 72).

Received: November $25^{\text {th }}, 2012$

Accepted: December $20^{\text {th }}, 2012$

\section{References}

Accart, Xavier (2001), L'Eremite de Duqqi: René Guénon en marge des milieux francophones égyptiens, Milan, Arche.

Accart, Xavier (2005), Guénon on Le renversements des clartés: influence d'un métaphysicient sur la vie littéraire et intellectuelle francaise (1920-1970), Paris, Edidit Sarl.

Aristoteles (1993), Analitica Posteriora, Wiley-VCH.

Barazzetti, Enrico (1997), L’Espace symbolique. Développements du symbolism mathématique des états multiples de l'Être, Milan, Arche.

Baeumker, Clemes (1927), Studien und Charakteristiken zur Geschichte der Philosophie insbesondere des Mittelalters, Münster, Aschendorff.

Chacornac, Paul (1958), La vie simple de René Guénon, Paris, Editions traditionnelles.

Feydel, Pierre (2003), Apercus historiques touchant à la fonction de René Guénon: suivi d’une étude bio-bibliographique, Milan, Arche.

Gilis, Charles-André (1986), Introduction à l'enseignement et au mystère de René Guénon, Paris, Editions traditionnelles.

Guénon, René (1962), "La Science des letters, Le mystère de la lettre Nûn”, in Symboles de la Science sacrée, Paris.

Guénon, René (1973), "Note sur l’angélologie de l’alphabet arabe, La chirologie dans l'ésotérisme islamique", in Apercus sur l'ésotérisme islamique et le Taoisme, Paris, Gallimard.

Guénon, René (1975), The Symbolism of the Cross, London, Luzac and Co. Ltd.

Guénon, René (1976), "Remarques sur la notation mathématique” in Mélanges par René Guénon, Paris, Gallimard. 
Guénon, René (1985), The Multiple States of Being, New York, Larson Publications. Guénon, René (1995), The Reign of Quantity and the Signs of Time, Hillsdale, NY: Sophia Perennis.

Guénon, René (1996), The crisis of the modern world (Collected Works of René Guénon), Ghent.

Guénon, René (2001a), Studies in Hinduism, Hillsdale, NY: Sophia Perennis.

Guénon, René (2001b), The Metaphysical Principles of the Infinitesimal Calculus, Hillsdale, NY: Sophia Perennis.

Guénon, René (2004), Introduction to the study of the Hindu doctrines (Collected Works of René Guénon), Hillsdale, NY: Sophia Perennis.

Laurant, Jean-Pierre (1975), Le sens caché dans l'œuvre de René Guénon, Paris, Lausanne: Editions l'age d'Homme.

Laurant, Jean-Pierre (2006), René Guénon: les enjeux d’une lecture, Paris, Dervy.

Lemaistre de Sacy, Louis-Isaac (2004), Lénigme René Guénon et les 'Supérieurs Inconnus': contributions à l'étude de l'histoire mondiale 'souterraine', Milan, Arche.

Lognetti, Giuseppe (1996), Larca perduta. Tradizione e critica del moderno in René Guénon, Florence, A. Pontecorboli.

Mahmud, 'Abd al-Halìm (2007), Un soufi d'Occident, Cairo, Al Bouraq.

Robin, Jean (1983), René Guénon: la dernière chance de l'Occident, Paris, Guy Trédaniel.

Robin, Jean (1986), René Guénon: témoin de la tradition, Paris, Guy Trédaniel.

Schuon, Frithjof (1979), "Studies in Comparative Religion", in The Journal of Traditional Studies "Sophia Perennis", 13: 133-137.

Schuon, Frithjof (2004), René Guénon: Some Observations, Hillsdale, NY: Sophia Perennis.

Sigaud, Pierre-Marie (1984), René Guénon, dossier conçu et dirigé, Paris, Lausanne: Editions l'age d'Homme.

Vivenza, Jean-Marc (2002), Le Dictionnaire de René Guénon, Grenoble, Mercure Dauphinois.

Vivenza, Jean-Marc (2004), La Métaphysique de René Guénon, Grenoble, Mercure Dauphinois.

Waterfield, Robin Everard (1987), René Guénon and the Future of the West, Wellingborough. 